\title{
Climate change and drought
}

Arnell N.W.

in

López-Francos A. (ed.).

Drought management: scientific and technological innovations

Zaragoza : CIHEAM

Options Méditerranéennes : Série A. Séminaires Méditerranéens; n. 80

2008

pages 13-19

Article available on line / Article disponible en ligne à l'adresse :

http://om.ciheam.org/article.php?IDPDF=800414

To cite th is article / Pou r citer cet article

Arnell N.W. Climate change an d drou ght. In : López-Francos A. (ed.). Drought management: scientific and technological innovations. Zaragoza : CIHEAM, 2008. p. 13-19 (Options Méditerranéennes : Série A. Séminaires Méditerranéens; n. 80)

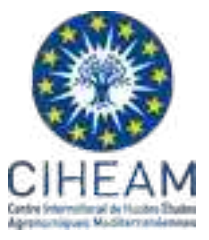

http://www.ciheam.org/

http://om.ciheam.orgl 


\title{
Climate change and drought
}

\author{
N.W. Arnell \\ Walker Institute for Climate System Research, Department of Meteorology, University of Reading, \\ Earley Gate, Reading RG6 6BB, UK
}

SUMMARY - Climate change is likely to increase drought risk during the $21^{\text {st }}$ century in many parts of the world. Climate model projections, under a range of emissions scenarios, consistently show that seasonal rainfall is likely to decrease across large parts of southern Europe, north Africa, central Asia and southern Africa, and reductions are also possible in other dry parts of the world. The effects of climate change, however, will be superimposed on the patterns of natural climatic variability - such as ENSO - and the effects of land cover change which also tends to lead to increased regional temperatures and lower regional rainfall. Quantitative estimates of change in drought risk are therefore very uncertain. Enhanced climate models, which can reproduce observed patterns of variability, will help reduce uncertainty in projected future changes, but drought management plans now need to begin to incorporate climate change. This can be done either through a scenario-based approach, where robustness of a plan is tested against different feasible "stories", or through a risk-based approach using estimates of the likelihoods of defined drought outcomes. Both approaches have advantages and disadvantages.

Key words: Climate change, drought, impacts, predictability, trends.

RESUME - "Changement climatique et sécheresse". Le changement climatique est susceptible d'augmenter les risques de sécheresse au cours du XXI siècle dans de nombreuses régions du monde. De plus, les projections des modèles climatiques montrent que les précipitations saisonnières sont susceptibles de diminuer dans de grandes parties du sud de l'Europe, en Afrique du Nord, en Asie centrale et en Afrique du Sud. D'autres régions sèches du monde pourraient aussi être touchées par ce phénomène. Les effets du changement climatique vont cependant se superposer aux structures de la variabilité climatique naturelle - telles que l'ENSO - et aux effets dus à la modification de la couverture terrestre qui conduit à des températures régionales accrues et à une baisse des précipitations régionales. II est donc difficile d'établir des estimations quantitatives de l'évolution des risques de sécheresse. Ainsi, une amélioration des modèles climatiques, qui peuvent reproduire les schémas de variabilité observés, contribuerait à réduire les incertitudes des changements futurs. Or les plans de gestion de sécheresse doivent commencer à intégrer les études de changement climatique. Cela pourrait se faire soit par le biais d'un scénario, où la robustesse du plan est testée avec différents déroulements plausibles, soit par une étude de risques basée sur les probabilités de sécheresses. Les deux approches ont leurs avantages et leurs inconvénients.

Mots-clés : Changement climatique, sécheresse, impacts, tendances.

\section{Introduction}

The Fourth Assessment Report of the Intergovernmental Panel on Climate Change (IPCC) concluded that warming of the climate system was unequivocal, was very likely to be due to the observed increase in anthropogenic greenhouse gas emissions, and that continued emissions of greenhouse gases would cause climate changes during the $21^{\text {st }}$ century that would very likely be larger than those observed during the $20^{\text {th }}$ century (IPCC, 2007). The report also concluded that altered frequencies and intensities of extreme weather are expected to have mostly adverse effects on natural and human systems, and, more specifically, that the area affected by drought is likely to increase. Meanwhile, the early $21^{\text {st }}$ century has seen significant and well-publicised droughts in many parts of the world, including southern Europe, south east USA, much of Australia, east Africa and large parts of China.

"Drought", however, is multi-faceted, and can be interpreted in many different ways. A meteorological drought is defined by a prolonged deficit of precipitation, an agricultural drought is characterised by soil moisture deficit, and a hydrological drought arises following reductions in river 
flows, reservoir and groundwater levels. The human consequences of a drought - whether meteorological, agricultural or hydrological - depend not only on the intensity, duration and extent of the physical climatic anomaly, but also on the exposure and vulnerability of human systems, and often on the challenges posed by other pressures. Moreover, the frequency of occurrence of droughts is very strongly influenced by the rhythms and patterns of natural climatic variability, and may be influenced by changes in land cover. The effects of an increasing concentration of greenhouse gases on "drought" and its "impacts" are therefore likely to be extremely complex.

This paper aims to summarise current understanding of the potential implications of climate change on drought (focusing on drought as a physical climatic anomaly and referring only briefly to the possible human consequences) and to identify ways in which projections of future drought occurrence can be improved. The paper begins by briefly reviewing trends in drought characteristics during the $20^{\text {th }}$ century, and concludes by considering the implications of climate change (and current understanding of it) for the management of droughts.

\section{Trends in drought occurrence during the $20^{\text {th }}$ century}

Assessments of trends in drought occurrence over a long time period need to employ consistent quantitative indicators which can readily be calculated from available data. The Palmer Drought Severity Index (PDSI) has been widely used (Dai et al., 2004; Burke et al., 2006). The index for a given time period is basically a function of the difference between actual precipitation and the amount of precipitation required to maintain a "normal" water balance level, where the amount required is a dependent on evaporation, soil water recharge and runoff as calculated using a very simple hydrological model. Figure 1 shows the dominant spatial pattern in the PDSI over the period 1900 to 2002, calculated from observed precipitation and temperature data (Dai et al., 2004; Trenberth et al., 2007). This analysis suggests that very dry areas (with a PDSI less than -3 ) increased from $12 \%$ of the global land surface to $30 \%$ since the 1970s. Drought occurrence increased particularly in western and southern Africa, southern Europe and North Africa, south Asia and eastern Australia. Part of this increase followed a large jump due to decreases in precipitation in large areas in the 1980s due to ENSO (see below), and part was due to increasing surface temperatures and therefore evaporation.

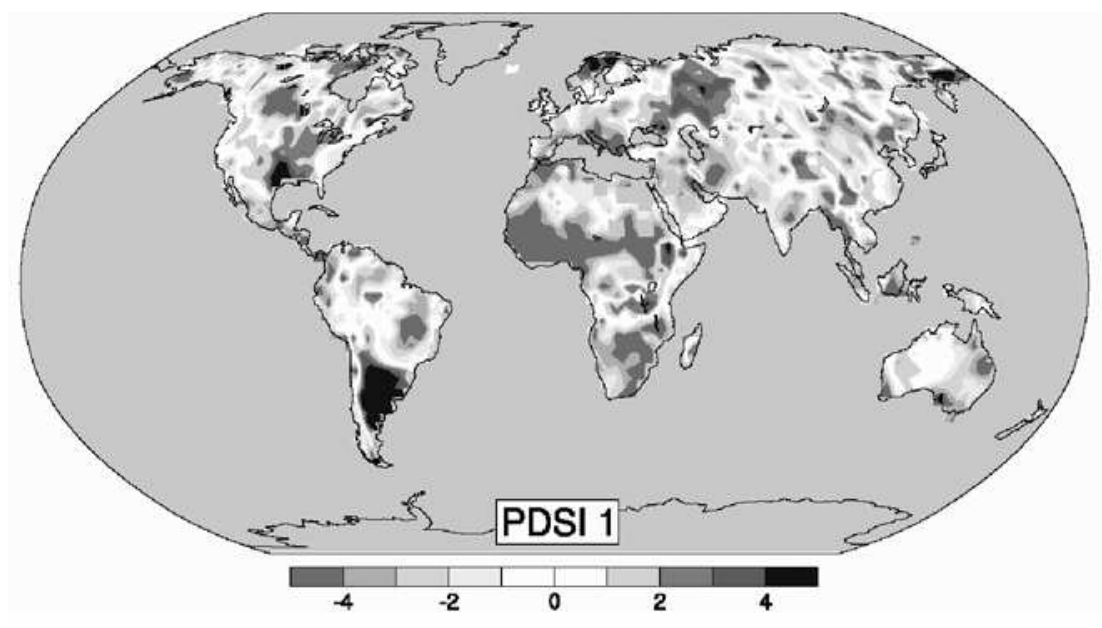

Fig. 1. The dominant spatial pattern in the monthly Palmer Drought Severity Index over the period 19002002. Areas with a drying trend have a negative index (Dai et al., 2004; Trenberth et al., 2007).

There are, however, a number of complications with the PDSI (including the need for local calibration, the time scale at which it is calculated, and the general use of the Thornthwaite formula to estimate potential evaporation), and different indicators of drought can give different indications of trends over time. Sheffield and Wood (2008), for example, used an indicator based on simulated soil moisture contents, and did not identify an underlying long-term trend towards increasing drought during the $20^{\text {th }}$ century. They did, however, find that in some regions there was a clear switch to a drying trend at the end of the $20^{\text {th }}$ century (Fig. 2), which they attribute to higher temperatures leading to increased evaporation and, in some regions, earlier snowmelt. 

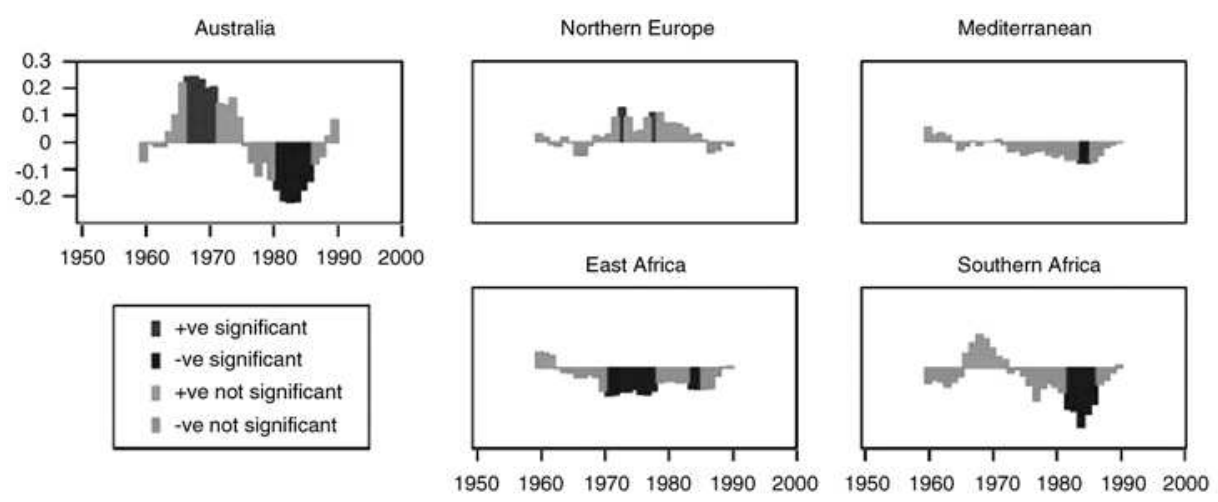

Fig. 2. Trends in regional average soil moisture for a 21-year moving window. Trends significant at the $5 \%$ level are shown in darker colours (Sheffield and Wood, 2008).

The occurrence of droughts is characterised by very considerable inter-annual variability. At the global scale this is driven by variability in ENSO, which primarily impacts upon the tropics and many mid-latitude regions. At the regional scale, other modes of large-scale variability become important, often in interaction with ENSO. For example, the North Atlantic Oscillation (NAO: characterising atmospheric variability), affects winter climate in eastern North America, much of Europe and North Africa, and effects can be identified across the Middle East. The Atlantic Meridional Oscillation (AMO: characterising variations in sea surface temperatures) affects summer climate around the North Atlantic Ocean in North America and western Europe. The Pacific Decadal Oscillation (PDO) influences climatic variability around the Pacific basin. Associations have been found between all these modes of variability and indicators of drought, making it extremely difficult to identify persistent trends in drought occurrence. Is an apparent increase in drought frequency in a region due to an underlying trend or simply part of a natural oscillation? And are these natural oscillations being affected by an underlying climate change?

There is also increasing evidence that historical changes in land cover have altered regional climates, contributing to altered frequencies of occurrence of drought by magnifying the effects of natural climatic variability [e.g. in Australia: McAlpine et al. (2007) and the Sahel: Taylor et al. (2002)].

\section{Droughts in the $21^{\text {st }}$ century}

The evolution of drought risk during the $21^{\text {st }}$ century will depend on both changes in climate (and consequent changes in meteorological, agricultural and hydrological drought) and changes in exposure to drought due to altered demographic and socio-economic conditions. This section focuses on the potential changes in climate which will impact upon drought risk, rather than possible changes in socio-economic conditions.

Projections of future climate are based on simulations using global climate models forced with assumed rates of change of greenhouse gas emissions and atmospheric concentrations. The Fourth Assessment Report of the IPCC provides an overview of the characteristics of these models and the broad patterns of climate change projected under a set of emissions scenarios (Meehl et al., 2007). A long-standing and robust result from climate model experiments is an increasing chance of summer drying in continental mid-latitudes, particularly in the Northern Hemisphere (Meehl et al., 2007). Figure 3 summarises the projected changes in mean seasonal rainfall by the end of the $21^{\text {st }}$ century (IPCC, 2007).

Burke et al. (2006) simulated changes in the PDSI over the $21^{\text {st }}$ century using the HadCM3 climate model driven by the SRES A2 scenario. They projected an overall drying trend, accelerating through the $21^{\text {st }}$ century, with particularly strong drying over Amazonia, the United States, northern Africa, southern Europe and eastern Asia. Under their projections, the percentage of land under "severe" drought increases from around $10 \%$ at the beginning of the $21^{\text {st }}$ century to around $40 \%$ at the end. The frequency of "severe" drought events doubles by the end of the century, and their mean duration increases by a factor of around five (Burke et al., 2006). There is, however, considerable uncertainty 
in the change in regional drought characteristics, depending not only on uncertainty in how climate will change but also on the indicators used to characterise droughts. Figure 4 shows the uncertainty in the range in change in the percentage of the land surface in drought for the Mediterranean region using four indicators of drought and multiple model simulations (Burke and Brown, 2008). For example, using the PDSI as a measure of drought, the change in drought area ranges from approximately 25 to $80 \%$; using an indicator based on soil moisture availability, the change is between 10 and $55 \%$.

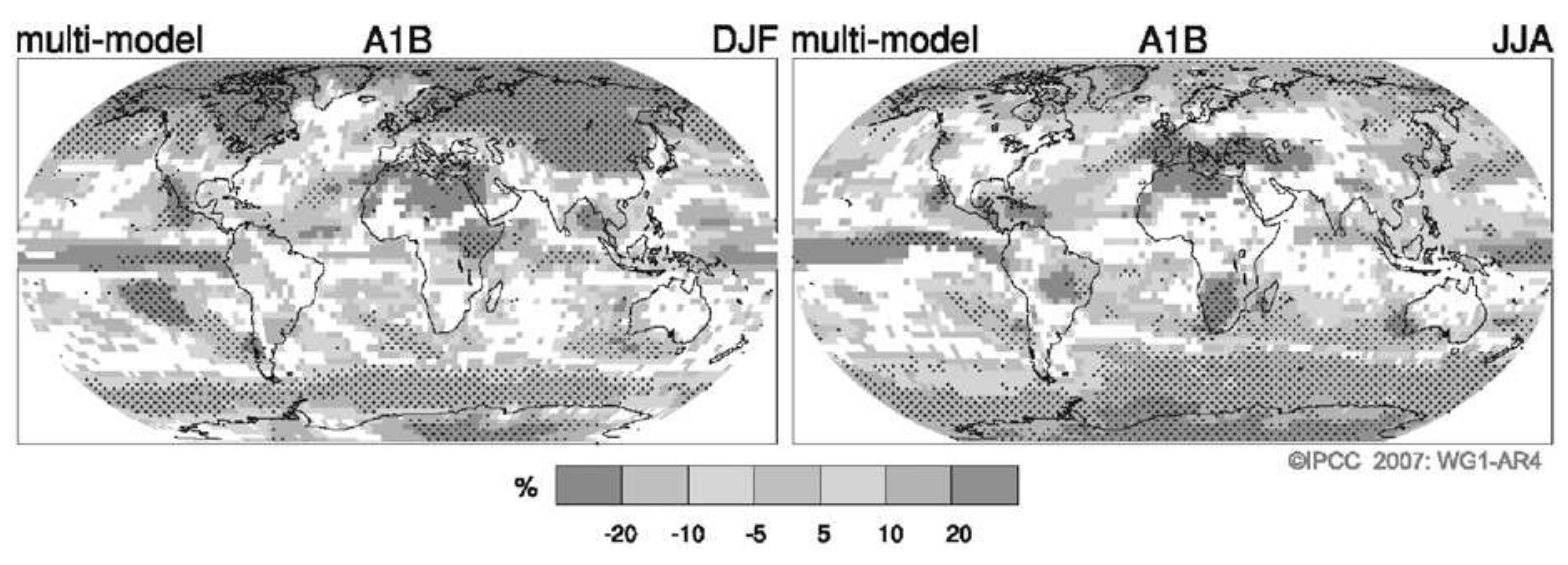

Fig. 3. Percentage change in mean December-February and June-August rainfall by the end of the $21^{\text {st }}$ century, under the SRES A1B scenario (IPCC, 2007). The figure shows the ensemble mean change from several climate models, with the stippled areas showing regions of strong agreement.

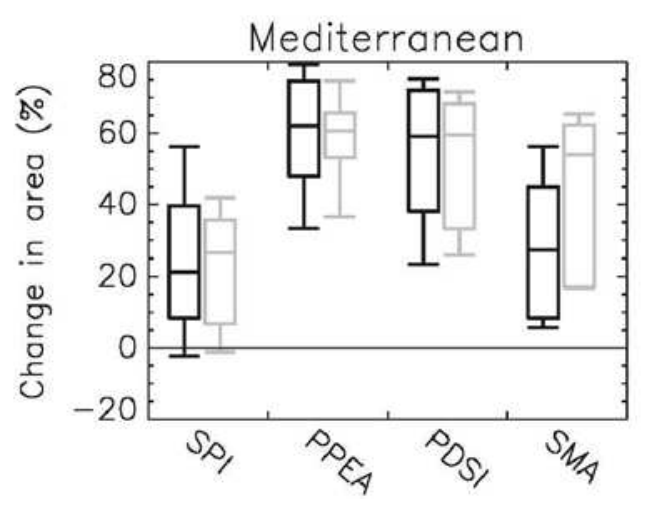

Fig. 4. Uncertainty in the change in the percentage of the land surface in drought in the Mediterranean region (Burkeand and Brown, 2008). The box shows the $25-75 \%$ uncertainty range, and the whiskers the $5-95 \%$ range; the dark and light boxes show different subsets of climate models.

Few studies have looked explicitly at hydrological drought. Lehner et al. (2006) found under two climate model projections a general significant increase in drought frequencies across southern and south-eastern Europe. By the 2070s in southern Europe, the streamflow drought that currently occurs on average once every 100 years could have a return period of less than 10 years. At the global scale, Arnell (2004) estimated that by the 2050s between 670 and 1500 million people living in waterstressed watersheds would see a significant reduction in water availability due to climate change, under a medium-growth population assumption (SRES B2). Most of these people would be around the Mediterranean, in the Middle East and central Asia, and southern Africa.

Changes in future drought occurrence, however, will be strongly influenced by changes in modes of climatic variability such as ENSO, the NAO and the PDO. Whilst global climate models are generally good at simulating mean climates, they are less good at simulating current modes of variability and the relationships between different parts of the world. The IPCC Fourth Assessment Report (Meehl et al., 2007) concluded that even amongst models which could simulate aspects of 
modes of variability, there was considerable uncertainty in the magnitude or direction of possible changes. All the models that could simulate (to some degree) current ENSO variability, for example, showed that variability would continue through the $21^{\text {st }}$ century, but that the details of changes varied considerably (Meehl et al., 2007). Similarly, whilst there was a general tendency towards an increasingly positive NAO (meaning storm tracks pass further to the north across Europe, leading to relatively low winter rainfall across southern Europe), the change was generally small but highly variable between models.

As noted in the previous section, there is evidence that changes in land cover have in the past affected regional climates, generally tending to lead to increased temperatures and lower rainfall. Land cover will continue to change in the $21^{\text {st }}$ century due to changes in land management practices, and will also change directly as climate changes. A small number of model simulation studies have compared the effects of increasing greenhouse gas concentrations and land cover change (typically deforestation), showing that whilst the additional global effects of land cover change are small, regional effects - leading to enhanced drought risk - may be more substantial (Meehl et al., 2007).

\section{Improving projections of future droughts}

It is clear from the previous section that, whilst broad patterns of future drought occurrence can be projected, there is considerable uncertainty in regional detail and quantitative change in drought risk (even using a given indicator of drought). Research is currently underway in three areas to help reduce this uncertainty.

First, it is becoming increasingly clear that improved simulation of the rhythms and patterns of year to year climatic variability (such as ENSO) and how they might change requires the use of high resolution global climate models. High spatial resolution - of the order of 60-100 km, rather than the 200-500 km of current global models - improves the simulation of ocean circulations and sea surface temperatures, and of small-scale interactions between the ocean and the atmosphere. This leads to enhanced simulation of year to year climatic variability and teleconnections between different parts of the world. For example, all aspects of the simulation of ENSO behaviour are improved in the high resolution model HiGEM than in its lower-resolution counterpart HadGEM (Shaffrey et al., 2008). However, such high-resolution global models are extremely computationally-intensive.

Second, in order to improve the simulation of hot and dry anomalous climatic events it is necessary to improve the simulation of the (positive) feedbacks between land surface and the atmosphere. During the 2003 European summer heat wave, for example, the lack of soil moisture reduced cooling due to evaporation and amplified substantially the surface temperature anomaly (Fischer et al., 2007). The simulation of these feedbacks can be improved using enhanced representations of land surface processes within climate models.

Third, over the next two or three decades climate change will be superimposed on patterns of climatic variability, and indeed may be small relative to this variability. Projections of possible future climates over the next two or three decades which just consider the effects of climate change, and which involve a comparison between a "baseline" climate and a "future" climate, will therefore understate the possible range in future climatic conditions (the difference in climate between the 2020s and a 1961-1990 baseline will be a function of the underlying climate change and any natural multi-decadal variability). Similarly, any projection of the next two or three decades which assumes no significant climate change and the continuation of present patterns of variability may also understate the range in possible climate futures. Techniques are therefore necessary to combine information on underlying climate changes with information on patterns of multi-decadal climatic variability. One way of approaching this is through adding random fluctuations to climate change projections; another is to take advantage of emerging skills in decadal climate forecasting. Improved understanding of the factors driving climatic variability, and improved observational data providing information on the state of the ocean and land surface, provide opportunities for "forecasts" of future climate which incorporate both natural variability and an underlying climate change (e.g. Smith et al., 2007; Keenlyside et al., 2008). Whilst these decadal forecasting approaches are in their infancy, they offer a potential for reducing uncertainty in climate projections over the next two or three decades in some regions of the world at least. 


\section{Conclusions}

This paper has summarised the potential effects of climate change on "physical" drought as characterised by some climatic anomaly; the real future drought risk will of course be strongly influenced by trends in exposure to drought and ability to react and recover. Whilst there is broad model agreement on a general tendency towards an increased (physical) drought risk, there is considerable uncertainty over the magnitude of this change and, particularly, on how changes in patterns of climatic variability will impact upon drought risk. Current modelling developments, summarised in the previous section, will address this in the next few years.

Drought management plans, however, need to take climate change into account now. Even if it is not possible to state with confidence how drought risk will change, it is possible to be completely confident that it is no longer credible to assume the risk will not change. There are two broad approaches to assessing the implications of climate change for a given system or sector.

The first can be termed a scenario-based approach, where the robustness of a plan is tested against different feasible futures. These different scenario futures are not predictions, but can be best thought of as credible stories. The SRES scenarios, widely used in climate impact assessments, are stories, not projections, as are the scenarios used in the Millennium Ecosystem Assessment or UNEP Global Environment Outlook. The value of a scenario-based approach is that it encourages the development of plans and strategies that are flexible and adaptable to altered circumstances. One disadvantage is that robustness may be overestimated if too narrow a range of scenarios is considered; another is that risks may be exaggerated if highly unrealistic scenarios are considered.

The second approach is risk-based, and uses probabilistic projections of future drought risk. Under this approach, climate (and other) scenarios are interpreted as forecasts, and assigned likelihoods of occurrence (e.g. Murphy et al., 2007). Adaptation plans are then designed to meet a defined "standard of service". Although there has been much interest in probabilistic projections of future climate and its impacts, there are a number of key problems. First, whilst it is possible conceptually to define probability distributions for some aspects of uncertainty (particularly those associated with the climate system), it is not possible to assign probabilities to those aspects which are inherently unpredictable (such as emissions pathways under different possible socio-economic futures). Second, it may be computationally challenging to construct probability distributions of indicators of impact; it is not possible to assign a likelihood to a scenario, and then assume that the same likelihood can be attached to the impacts of that scenario. Finally, probability distributions of future impacts will be misleading if key sources of uncertainty - such as the effect of natural climatic variability - are omitted, and may be highly dependent on methodologies used (New et al., 2007).

Regardless of which approach is followed, however, climate change challenges some of the key (often implicit) assumptions in drought management. It is no longer feasible to assume that the past is the key to the future. Whilst it is necessary to ensure that drought management plans can cope with current climatic variability, this is not in itself sufficient to ensure that these plans can cope with possible changes in drought risk. Finally, uncertainty in projected future drought risk encourages the use of flexible and robust measures which can be readily adapted and altered as more information is gathered.

\section{References}

Arnell, N.W. (2004). Climate change and global water resources: SRES emissions and socioeconomic scenarios. Global Environmental Change, 14(1): 31-52.

Burke, E.J. and Brown, S.J. (2008). Evaluating uncertainties in the projection of future drought. Journal of Hydrometeorology, 9(2): 292-299.

Burke, E.J., Brown, S.J. and Christidis, N. (2006). Modeling the recent evolution of global drought and projections for the twenty-first century with the Hadley Centre climate model. Journal of Hydrometeorology, 7(5): 1113-1125.

Dai, A., Trenberth, K.E. and Qian, T. (2004). A global dataset of Palmer Drought Severity Index for 1870-2002: Relationship with soil moisture and effects of surface warming. Journal of Hydrometeorology, 5(6): 1117-1130. 
Fischer, E.M., Seneviratne, S.I., Vidale, P.L., Lüthi, D. and Schär, C. (2007). Soil moisture Atmosphere interactions during the 2003 European summer heat wave. Journal of Climate, 20(20): 5081-5099.

IPCC (2007). Climate Change 2007: Synthesis Report. Contribution of Working Groups I, II and III to the Fourth Assessment Report of the Intergovernmental Panel on Climate Change. Geneva, Switzerland, IPCC.

Keenlyside, N.S., Latif, M., Jungclaus, J., Kornblueh, L. and Roeckner, E. (2008). Advancing decadalscale climate prediction in the North Atlantic sector. Nature, 453(7191): 84-88.

Lehner, B., Doll, P., Alcamo, J., Henrichs, T. and Kaspar, F. (2006). Estimating the impact of global change on flood and drought risks in Europe: A continental, integrated analysis. Climatic Change, 75(3): 273-299.

McAlpine, C.A., Syktus, J., Deo, R.C., Lawrence, P.J., McGowan, H.A., Watterson, I.G. and Phinn, S.R. (2007). Modeling the impact of historical land cover change on Australia's regional climate. Geophysical Research Letters, 34(22). doi: 10.1029/2007GL031524.

Meehl, G.A., Stocker, T.F., Collins, W.D., Friedlingstein, P., Gaye, A.T., Gregory, J.M., Kitoh, A., Knutti, R., Murphy, J.M., Noda, A., Raper, S.C.B., Watterson, I.G., Weaver, A.J. and Zhao, Z.-C. (2007). Global Climate Projections. In: Climate Change 2007: The Physical Science Basis, contribution of Working Group I to the Fourth Assessment Report of the Intergovernmental Panel on Climate Change, Solomon, S., Qin, D., Manning, M., Chen, Z., Marquis, M., Averyt, K.B., Tignor, M. and Miller, H.L. (eds). Cambridge University Press, Cambridge, pp. 747-845.

Murphy, J.M., Booth, B.B.B., Collins, M., Harris, G.R., Sexton, D.M.H. and Webb, M.J. (2007). A methodology for probabilistic predictions of regional climate change from perturbed physics ensembles. Philosophical Transactions of the Royal Society a-Mathematical Physical and Engineering Sciences, 365(1857): 1993-2028.

New, M., Lopez, A., Dessai, S. and Wilby, R. (2007). Challenges in using probabilistic climate change information for impact assessments: An example from the water sector. Philosophical Transactions of the Royal Society a-Mathematical Physical and Engineering Sciences, 365(1857): 2117-2131.

Shaffrey, L., Stevens, I., Norton, W., Roberts, M., Vidale, P.-L., Harle, J., Jrrar, A., Stevens, D., Woodage, M., Demory, M.-E., Donners, J., Clark, D., Clayton, A., Cole, J., Wilson, S., Connolley, W., Davies, T., Iwi, A., Johns, T., King, J., New, A., Slingo, J., Slingo, A., Steenman-Clark, L. and Martin, G. (2008). UK-HiGEM: The new UK high resolution global environment model. Journal of Climate (in press).

Sheffield, J. and Wood, E.F. (2008). Global trends and variability in soil moisture and drought characteristics, 1950-2000, from observation-driven simulations of the terrestrial hydrologic cycle. Journal of Climate, 21(3): 432-458.

Smith, D.M., Cusack, S., Colman, A.W., Folland, Ch.K., Harris, G.R. and Murphy, J.M. (2007). Improved surface temperature prediction for the coming decade from a global climate model. Science, 317(5839): 796-799.

Taylor, Ch.M., Lambin, E.F., Stephenne, N., Harding, R.J. and Essery, R.L.H. (2002). The influence of land use change on climate in the Sahel. Journal of Climate, 15(24): 3615-3629.

Trenberth, K.E., Jones, P.D., Ambenje, P., Bojariu, R., Easterling, D., Tank, A.K., Parker, D., Rahimzadeh, F., Renwick, J.A., Rusticucci, M., Soden, B. and Zhai, P. (2007). Observations: Surface and atmospheric climate change. In: Climate Change 2007: The Physical Science Basis, contribution of Working Group I to the Fourth Assessment Report of the Intergovernmental Panel on Climate Change, Solomon, S., Qin, D., Manning, M., Chen, Z., Marquis, M., Averyt, K.B., Tignor, M. and Miller, H.L. (eds). Cambridge University Press, Cambridge, pp. 235-336. Observations: surface and atmospheric climate change. Climate Change 2007: The Physical Science Basis. Contribution of Working Group 1 to the Fourth Assessment Report of the Intergovernmental Panel on Climate Change. 